\title{
Effects of PCR-confirmed subclinical paratuberculosis on retinol and $\beta$-carotene levels in dairy cattle
}

\author{
Efectos de paratuberculosis subclínica confirmada por PCR en los niveles de retinol \\ y $\beta$-caroteno de ganado lechero
}

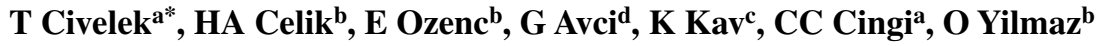 \\ ${ }^{a}$ Department of Internal Medicine, Faculty of Veterinary Medicine, University of Afyon Kocatepe, Afyonkarahisar, Turkey. \\ ${ }^{b}$ Department of Obstetrics and Gynaecology, Faculty of Veterinary Medicine, University of Afyon Kocatepe, \\ Afyonkarahisar, Turkey. \\ 'Department of Microbiology, Faculty of Veterinary Medicine, University of Selçuk, Konya, Turkey. \\ dDepartment of Biochemistry, Faculty of Veterinary Medicine, University of Afyon Kocatepe, Afyonkarahisar, Turkey.
}

\section{RESUMEN}

\begin{abstract}
En el presente estudio se investigaron los efectos de la paratuberculosis subclínica en las concentraciones séricas de betacaroteno y retinol en ganado lechero. Se utilizaron 30 vacas lecheras multíparas y no vacunadas de raza Holstein, de 3 a 9 años de edad. 15 de las 30 vacas fueron diagnosticadas subclínicamente positivas a paratuberculosis mediante PCR (grupo 1). Las 15 vacas restantes fueron clasificadas como grupo control (grupo 2) que estaba sano. Los niveles de retinol y de betacaroteno del suero fueron analizados por análisis colorimétrico en todas las muestras. No hubo diferencias con respecto a las concentraciones de retinol y de betacaroteno de suero entre los grupos.
\end{abstract}

Key words: retinol, dairy cow, paratuberculosis, beta-carotene.

Palabras clave: retinol, vaca lechera, paratuberculosis, betacaroteno.

\section{INTRODUCTION}

Paratuberculosis (pTB) is a chronic, fatal inflammatory disease in ruminants caused by Mycobacterium avium subsp. paratuberculosis (Mycobacterium paratuberculosis). It is characterised by a long "subclinical" stage of infection. Most infected cattle do not shed detectable numbers of the $M$. paratuberculosis bacteria in faeces until after two years of age. At this early infection stage, although some possible gut damage has occurred, the cattle do not show clinical signs of pTB and thus are referred to as cases of "subclinical pTB" (Allaker et al 2003, Baumgartner and Khol 2006). During this stage of the disease these cattle are infectious, i.e. capable of infecting other members of the herd (Baumgartner and Khol 2006).

Vitamin A activity is defined in retinol equivalents. Retinol is not found in plants but these do contain a retinol precursor called beta-carotene. Beta-carotene is converted to retinol by enzymes located in cells of the intestinal mucosa (Nagao 2004). There is no information about whether serum beta-caroten and retinol concentrations are affected by pTB. We hypothesized that bovine paratuberculosis causes damage to the gut leading to diminished levels of

Accepted: 14.07.2009.

* tcivelek@aku.edu.tr serum retinol. No prior publications explored this question so the aim of this study was to investigate variations in serum beta-carotene and retinol concentrations in dairy Holstein cattle with pTB.

\section{MATERIAL AND METHODS}

\section{ANIMALS AND SAMPLES}

A total of 30 cycling, paratuberculosis non-vaccinated multiparous Holstein dairy cows were selected from a farm situated near the Afyonkarahisar, Turkey. The average ages were $4.25 \pm 0.77$ years in the control group $(n=15)$ and $6.50 \pm 1.91$ years in the subclinical pTB group $(n=15)$. Both groups were similar by body condition score (BCS) and stage of lactation. All of the selected cows in Group $1(\mathrm{n}=15)$ tested positive by intradermal Johnin test, Ziehl-Neelsen's stain (ZN) of faeces and IS900 polymerase chain reaction (PCR), whereas the 15 healthy dairy controls cows were negative on all three diagnostic tests for pTB (Group 2). There was no difference regarding the feed consumption between Group 1 and 2. All cows were being fed the same ration; alfalfa hay (30.9\%), barley hay (51.6\%) and concentrates (17.5\%). BCS were evaluated by the same person using methods as described by Edmonson et al $1989 ; 0=$ very thin to $5=$ grossly fat). All the cattle in Group 1 and Group 2 had an optimal BCS, i.e. 2.75 and 3.50 . 


\section{BIOCHEMICAL ANALYSES}

Blood samples were collected from the jugular vein into non-heparinized glass tubes and after coagulation at room temperature $\left(22-24^{\circ} \mathrm{C}\right)$ samples were centrifuged at $5000 \mathrm{rpm}$ for 15 minutes at room temperature and serum samples were stored at $-20^{\circ} \mathrm{C}$ until biochemical analysis. Serum retinol and beta-carotene concentrations were analysed by spectrophotometric assay according to method of Suzuki and Katoh (1990).

\section{BACTERIOLOGICAL ANALYSES}

The cows were tested concurrently with intradermal skin test and IS900 PCR methods. Direct examinations of samples with Ziehl-Neelsen's stain were also performed directly on all faecal and milk samples (Giese and Ahrens 2000, Salem et al 2005). Intradermal Johnin testing using purified protein derivative (PPD) obtained from Central Veterinary Control and Research Institute, Etlik, Ankara, Turkey was performed as described by Sikes and Groth 1950. Briefly, $0.1 \mathrm{ml}$ of avian PPD tuberculin was inoculated intradermally into shaved skin on the side of the middle third of the neck. The skin thickness was measured with calipers before and 72 hours after inoculation. Increases in skin thickness of over $3 \mathrm{~mm}$ were regarded as indicating the presence of delayed-type hypersensitivity to $M$. paratuberculosis, i.e. a positive test ${ }^{1}$. Detection of $M$. paratuberculosis in faeces and milk was done by IS900 PCR (Giese and Ahrens 2000, Soltani et al 2008). All the Johnin and ZN-positive cows selected for this study were also IS900 PCR-positive on both faeces and milk samples.

DNA extraction from raw milk. $15 \mathrm{ml}$ raw milk samples were centrifuged at $20,000 \mathrm{~g}$ for $1 \mathrm{~h}$ at $4{ }^{\circ} \mathrm{C}$. Supernatants were discarded. The pellets were washed in $1 \mathrm{ml}$ PBS, and finally resuspended in $500 \mu \mathrm{l}$ molecular biology grade water. Resuspended cell pellets were boiled in a water bath for $20 \mathrm{~min}$ and centrifuged at 10,000 $\mathrm{g}$ for 5 min at $+4{ }^{\circ} \mathrm{C}$. Then, DNA extracts were prepared using $6 \mathrm{M}$ guanidium thiocyanate, and crude DNA was extracted by using Promega Wizard resin (Promega, USA) as specified by the manufacturer. Aliquots $(5 \mu \mathrm{l})$ of purified DNA were tested by IS900 PCR (Cetinkaya et al 2000, Soltani et al 2008).

DNA Extraction from faeces samples. $200 \mathrm{mg}$ amount of faces was thoroughly suspended in $1 \mathrm{ml}$ of lysis buffer [(50 mM EDTA, 50 mM Tris-HCl, 0.5\% Tween 20, 0.5\% Triton X-100 (pH 8.0)] and then boiled for $20 \mathrm{~min}$. after $30 \mathrm{~s}$ of sonication with an ultrasonicator (Ultrasonic

Anonymous. 2007. World Organisation for Animal Health (OIE) Web site. Paratuberculosis (Johne's disease). Available at: www. oie.int/eng/normes/MMANUAL/A_00045.htm Accessed Jan 29.
Processor GE 130, Newton, USA) to ensure complete lysis. The suspension was centrifuged (10,000 g, $10 \mathrm{~min})$ to remove particles. The DNA samples were incubated (30 $\left.\mathrm{min}, 37^{\circ} \mathrm{C}\right)$ in the presence of RNase A $3 \mu \mathrm{l}(0.2 \mathrm{mg} / \mathrm{ml}$; Promega) and proteinase K $20 \mu \mathrm{l}(0.5 \mathrm{mg} / \mathrm{ml}$; Promega). The Wizard Genomic DNA purification kit (Promega, USA) was modified and used for DNA extraction and aliquots $(5 \mu \mathrm{l})$ of purified DNA were tested by IS900 PCR (Soltani et al 2008).

Confirmation of PCR amplification. PCR specificity was confirmed by comparison with the published $M$. paratuberculosis IS900 sequence on the EMBL GenBank DNA sequence database (Accession number X16293). We selected two primer pairs for $M$. paratuberculosis. The nested-PCR product spans nucleotides 54-379 bp of this sequence and yields a 326 bp PCR product.

IS900-Specific Nested-PCR. Enzymatic amplification of DNA was performed by a nested PCR technique described previously (Sanderson at al 1992). The outer and inner nested PCR primer pairs were used in this study. These primers were previously published and selected from IS900 sequence (GeneBank Acc. No. X16293) (Sanderson et al 1992). For the IS900 PCR, the first-round PCR mixture comprised $5 \mu \mathrm{l}$ of DNA sample extract in a final volume of $50 \mu \mathrm{l}$ with $1 \mu \mathrm{M}$ (each) outer primers, IS900-MAPOF1 (5'-GAAGGGTGTTCGGGGCCGTCGCTTAGG-3') and IS900-MAPOR1 (5'-GGCGTTGAGGTCGATC GCCCACGTGAC-3'); 1 X Taq buffer with $\mathrm{KCl}$ (Fermentas, Germany), $1.5 \mathrm{mM} \mathrm{MgCl}$, $200 \mu \mathrm{M}$ (each) dATP, dGTP, dCTP, and dTTP; and $1 \mathrm{U}$ Taq polymerase. Cycling conditions were 1 cycle of $95{ }^{\circ} \mathrm{C}$ for 15 minute and then 40 cycles of $94{ }^{\circ} \mathrm{C}$ for 1 minute, $58{ }^{\circ} \mathrm{C}$ for 1 minute, and $72{ }^{\circ} \mathrm{C}$ for $3 \mathrm{~min}$, followed by 1 cycle of $72{ }^{\circ} \mathrm{C}$ for 2 minutes. For the nested PCR, $2 \mu \mathrm{l}$ of the first-round reaction mixture was added to a $50 \mu \mathrm{l}$ reaction mixture that had the same ingredients as the primary reaction mixture but with $1 \mu \mathrm{M}$ (each) primers IS900-MAPNF1 (5'-CAGGGACGTCGGGTATGGCTTTCA-3') and IS900MAPNR1 (5'-CGTCACCGCCGCAATCAACTCCAG-3'). The cycling conditions were 1 cycle of $95^{\circ} \mathrm{C}$ for 5 min and then 30 cycles of $94{ }^{\circ} \mathrm{C}$ for $1 \mathrm{~min}, 55^{\circ} \mathrm{C}$ for $1 \mathrm{~min}$, and $72{ }^{\circ} \mathrm{C}$ for $3 \mathrm{~min}$, followed by 1 cycle of $72^{\circ} \mathrm{C}$ for 2 minutes. Faeces and milk samples were each tested in triplicate with a simultaneous, non-template PCR negative control and process controls. Nested-PCR amplification products (326 bp) were analyzed by $1.5 \%$ agarose gel electrophoresis. Gels were stained with ethidium bromide.

\section{STATISTICAL ANALYSIS}

The case definition of subclinical paratuberculosis was clinically normal cattle positive to all three paratuberculosis diagnostic tests. Controls were cattle from the same herd that were clinically healthy but negative to all three 
Table 1. The mean age, birth number and mean maximum milk yield values between Group 1 and Group 2 cows.

Valores promedios de edad, número de parto y producción de leche máxima en las vacas del Grupo 1 y del Grupo 2.

\begin{tabular}{lcccc}
\hline Groups & $\mathrm{n}$ & Age $(\mathrm{y})$ & Birth number & Maximum milk yield $(\mathrm{kg})$ \\
\hline PTb $(+)($ Group1) & 15 & $6.50 \pm 1.91^{\mathrm{a}}$ & $3.07 \pm 0.37^{\mathrm{a}}$ & $23.1 \pm 1.31^{\mathrm{a}}$ \\
$\mathrm{PTb}(-)$ (Group2) $^{*}$ & 15 & $4.25 \pm 0.77^{\mathrm{b}}$ & $1.62 \pm 0.21^{\mathrm{a}}$ & $23.3 \pm 2.30^{\mathrm{a}}$ \\
\hline
\end{tabular}

Different letters show $\mathrm{P}<0.05($ mean $\pm \mathrm{SD})$.

* $\mathrm{PTb}(+)$, paratuberculosis positive group; $\mathrm{PTb}(-)$, paratuberculosis negative group.

Table 2. Alterations between first-previous and current lactation period milk yield for the cows in Group1 and Group 2. Alteraciones entre los períodos inmediatamente anteriores y actuales de la lactancia en las vacas del Grupo 1 y del Grupo 2.

\begin{tabular}{lccc}
\hline \multirow{2}{*}{ Groups } & $\mathrm{n}$ & \multicolumn{2}{c}{ Lactation period milk yield $(\mathrm{kg})$} \\
\cline { 3 - 4 } & & Previous & Current \\
\hline PTb $(+)($ Group1) & 15 & $10,454.07 \pm 1,772.513^{\mathrm{a}}$ & $7,803.93 \pm 1,638.150^{\mathrm{b}}$ \\
$\mathrm{PTb}(-)(\text { Group} 2)^{*}$ & 15 & $7,085.46 \pm 1,857.261^{\mathrm{a}}$ & $6,669.11 \pm 612.35^{\mathrm{ab}}$ \\
\hline
\end{tabular}

Different letters show $\mathrm{P}<0.05$ (mean $\pm \mathrm{SD})$.

* $\mathrm{PTb}(+)$, paratuberculosis positive group; $\mathrm{PTb}(-)$, paratuberculosis negative group.

paratuberculosis tests. Data was analyzed using the t-test in SPSS statistical program for Windows (SPSS Inc.). All data were expressed as Mean \pm SD. Differences were considered significant at $\mathrm{P}<0.05$.

\section{RESULTS AND DISCUSSION}

Mycobacterium paratuberculosis was detected by nested IS900 in PCR both faecal and milk samples from all cows in group 1; cows with subclinical pTB. These cattle were clinically normal. Additionally, according to farm records dating back to two years these cows had not suffered from any periparturient diseases including retained placentas, ketosis, displaced abomasum, milk fever or mastitis.

Cows with subclinical pTB were older but had lower maximum milk yields than controls (table 1). Lower milk yields are consistent with the impact of pTB on milk production. The higher mean age is expected given the chronic insidious nature of $M$. paratuberculosis infections (time required for diagnostic tests to become positive) and the absence of any prior testing and culling program for $\mathrm{pTB}$ in the herd selected for the study (Buergelt and Duncan 1978, Allaker et al 2003, Baumgartner and Khol 2006).

When milk production from the current lactation was compared with that of the previous lactation, cattle with subclinical pTB had significantly lower values than controls. Benedictus et al (1987), reported that milk production for dairy cattle with subclinical pTB was decreased by $16 \%$ and $6 \%$ for the current and previous lactations, respectively. Abbas et al (1983), recorded a $15 \%$ reduction in the annual average milk yield from subclinically $M$. paratuberculosis-infected dairy cattle in comparison with controls. The present study revealed
Table 3. $\beta$-carotene and retinol values between groups of cows. Valores del $\beta$-caroteno y del retinol entre los grupos de vacas.

\begin{tabular}{lccc}
\hline Groups & $\mathrm{n}$ & $\begin{array}{c}\beta-\text { Carotene } \\
(\mu \mathrm{g} / \mathrm{dl})\end{array}$ & $\begin{array}{c}\text { Retinol } \\
(\mu \mathrm{g} / \mathrm{dl})\end{array}$ \\
\hline $\mathrm{PTb}(+)($ Group1)* & 15 & $102.92 \pm 26.63$ & $88.85 \pm 25.69$ \\
$\mathrm{PTb}(-)($ Group2) & 15 & $134.34 \pm 23.58$ & $103.6 \pm 31.18$ \\
\hline
\end{tabular}

Different letters show $\mathrm{P}<0.05$ (mean $\pm \mathrm{SD}$ ).

* $\mathrm{PTb}(+)$, paratuberculosis positive group; $\mathrm{PTb}(-)$, paratuberculosis negative group.

that milk production in the last lactation for Group 1 and Group 2 was decreased $25.36 \%$ and $5.87 \%$ respectively when comparing the current and previous lactations (table 2). This magnitude of production decrease was greater than reported in aforementioned studies, possibly because although the cases of subclinical pTB studied were clinically normal dairy cattle, the fact that all cases tested positive to three different diagnostic tests, including PCR on both faeces and milk, the animals may have been in a more advanced stage of the infection and thus experiencing larger effects due to the infection.

There were no differences regarding serum retinol and beta-carotene levels between groups (table 3 ). Thus, contrary to our hypothesis, subclinical pTB had no effect on serum levels of retinol or $\beta$-carotene. This is the first report on interactions between subclinical pTB and these compounds which are absorbed from the intestine. Alterations in serum retinol and beta-carotene concentrations were expected due to intestinal damage resulting from the $M$. paratuberculosis infection and subsequent inflammation and gut damage. 
Accordingly, serum retinol and beta-carotene may not be useful parameters for evaluation of gut damage in dairy cattle due to subclinical pTB.

\section{SUMMARY}

In the present study, the effects of IS900 PCR-confirmed subclinical paratuberculosis on serum beta-carotene and retinol concentrations in dairy cattle were investigated. A total of 30 multiparous, clinically normal, paratuberculosis non-vaccinated Holstein dairy cows, ages 3 to 9 years old were tested. Fifteen of the 30 cows were diagnosed as having subclinical paratuberculosis by IS900 PCR on faecal samples (Group 1). The remaining 15 cows, negative to three independent tests for paratuberculosis, were classified as the healthy control group (Group 2). Serum retinol and beta-carotene levels were analyzed by colorimetric assays on serum samples from all 30 cows. There were no differences regarding the serum retinol and beta-carotene concentrations between cows with and without paratuberculosis.

\section{REFERENCES}

Abbas B, HP Riemann, DW Hird. 1983. Diagnosis of Johne's disease (paratuberculosis) in Northern California cattle and a note on its economic significance. California Veterinarian J 8, 20-24.

Allaker RP, S Kapas. 2003. Adrenomedullin Expression by Gastric Epithelial Cells in Response to Infection. Clin Diagn Lab Immunol $10,546-551$.

Baumgartner W, JL Khol. 2006. Paratuberculosis (Johne's disease) in Ruminants-an ongoing story. Slov Vet Res 43, 5-10.

Benedictus G, AA Dijkhuizen, J Stelwagen. 1987. Economic losses due to paratuberculosis in dairy cattle. Vet Rec 121, 142-146.
Buergelt CD, JR Duncan. 1978. Age and milk production data of cattle culled from a dairy herd with paratuberculosis. J Am Vet Med Assoc 173, 478-480.

Cetinkaya B, A Muz, HB Ertas, H Ongor, IY Sezen, HB Gulcu. 2000. Determination of prevalence of paratuberculosis in dairy cattle by polymerase chain reaction (PCR). Turkish Journal of Veterinary \& Animal Sciences 24, 371-379.

Edmonson AJ, IJ Lean, LD Weaver, T Farver, G Webster. 1989. A body condition scoring chart for Holstein dairy cattle. J Dairy Sci 72, 68-78.

Giese SB, P Ahrens. 2000. Detection of Mycobacterium avium subsp. paratuberculosis in milk from clinically affected cattle by PCR and culture. Vet Mic 77, 291-297.

Hendrick SH, DF Kelton, KE Leslie, KD Lissemore, M Archambault, TF Duffield. 2005. Effect of paratuberculosis on culling, milk production, and milk quality in dairy herds. J Am Vet Med Assoc 227, 1302-1308.

Nagao A. 2004. Oxidative conversion of carotenoids to retinoids and other products. J Nutr 134, 237-240.

Salem M, AA Zeid, D Hassan. 2005. Studies on Johne's Disease in Egyptian Cattle. J Vet Med B 52, 134-137.

Sanderson JD, MT Moss, ML Tizard, J Hermon-Taylor. 1992. Mycobacterium paratuberculosis DNA in Crohn's disease tissue. Gut 33, 890-896.

Sikes D, AH Groth. 1950. Studies with the Johnin and tuberculin intradermal tests in cattle naturally infected with Mycobacterium paratuberculosis (Johne's disease). Am J Vet Res 11, 181-187.

Soltani M, MR Nassiry, FE Shahroudi and MR Bassami. 2008. Detection of Mycobacterium paratuberculosis in Feces and Milk Samples from Holstein Dairy Cows by PCR. Biotechnology 7, 582-585.

Suzuki J, N Katoh. 1990. A simple and cheap methods for measuring serum vitamin-A in cattle using only a spectrophotometer. Nippon Juigaku Zasshi 52, 1281-1283. 